\section{UNIVERSITY \\ OF DEBRECEN}

FACULTY OF

HeALTH

NYíREGYHÁZA

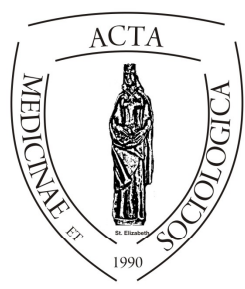

ACTA

MedSoc

VOLUMe 8.

2017

\title{
A vidék változása
}

\section{Ludescher Gabriella}

\section{Debreceni Egyetem Egészségügyi Kar}

\begin{abstract}
Absztrakt. A tanulmány a vidéki térségek átalakulási folyamatát mutatja be az elmúlt fél évszázad során, két kutatásra, illetve adatbázisra alapozva, melyet kiegészít más szakirodalmi és megfigyelési ismeretekkel is. Az első forrás Enyedi György (1980) Falvaink sorsa címü írása, mely egy nagy formátumú regionalista kutatónak harminc éves falu kutatási eredményeit foglalja össze. Másik forrásként a szerző a KSH (2015) városok és falvak statisztikai adatainak elemzését használja fel. E források segítségével és másodelemzésével nyomon követhetővé és számszerüsíthetővé válik a vidéki térségek átalakulása.

Az elemzés eredményei azt igazolják, hogy a vizsgált térségek átalakulóban vannak, mind demográfiailag, mind gazdaságilag, miközben egy erős funkcióvesztést szenvednek el. Ez a változás kihat a lakosság életmódjára, gondolkodására és közösségi életére is.
\end{abstract}

Kulcsszavak: vidéki térségek, közösségek, változás, átalakulás

Abstract. The paper presents the transformation process of the rural area in the past half century. It is based on the data of two studies, completed by knowledge from other literature and observation resources. The first inspiration is Enyedi György's work (1980) Falvaink sorsa (The Fate of our Villages), which presents the results of a 30-year research of villages by a remarkable regionalist writer. As a second resource the author uses the data of the KSH's (Central Statistial Office 2015) analyzis of towns and villages. With the help of the above listed research the changes of the rural area becomes trackable and quantifiable. 
The outcome of the study confirms that the observed areas are constantly changing from both demographic and economic point of view; they also suffer a strong loss of function. This alteration affects the way of life, thinking and community life of the population.

Keywords: rural areas, communities, changes, transformation.

DOI: $10.19055 / \mathrm{ams} .2017 .8 / 25 / 3$

\section{Bevezetés}

A magyar vidék változásának vizsgálatát végezhetnénk keresztmetszeti vagy longitudinális módszerekkel egyaránt. E két módszert a jelen tanulmány egyszerre kívánja használni úgy, hogy Enyedi György (1980) Falvaink sorsa címü könyvében megjelent, 30 év folyamatai t átfogó vizsgálati eredményeit veszi figyelembe a trendek megrajzolásához. Fontos megemlíteni, hogy már jelent meg ilyen öszszehasonlító írás Csatári Bálint (2012) tollából is, aki az Enyedi György által 1980-ban leírt fontos tudományos megállapításokat szembesítette az akkori magyar állapotokkal. A jelenlegi írás abban tér el az említettől, hogy a KSH (2015) adatait is felhasználja arra a célra, hogy bemutassa a vidék jelen állapotát, egyúttal a változások bemutatásához más adatokat is figyelembe vesz.

Enyedi (1980) a falvak jövőjét illetően három forgatókönyvet tudott elképzelni. Az első, hogy a városnövekedés megáll, $\mathrm{s}$ ismét a falusi települések fognak gyorsabban növekedni. „A második eshetőség, hogy a falu és a város hosszú távon fennmarad, miközben belső tartalmuk, kapcsolataik jellege és egymáshoz viszonyított arányuk is megváltozik. A harmadik a falu eltünése, a városi életforma és településforma kizárólagossá válása" (Enyedi, 1980:13-14). Enyedi a második eshetőséget látta a legvalószínübbnek. Több mint harmincöt év elteltével vizsgáljuk meg közelebbről, hogy melyik eshetőség látszik megvalósulni.

Senki számára sem kérdéses, hogy falvaink egy állandó változáson mennek át, melyet jól nyomon követhetünk azzal, hogy ha csak végig sétálunk egy vidéki település utcáin és megnézzük a közintézményeket, boltokat, házakat és azok telkeit. Napjainkban a falvaink, vidéki térségeink lakosságának föfoglalkoztatottságát nem a mezőgazdaság adja, nem helyben dolgoznak, a fiatalok sok esetben nem helyben járnak óvodába, általános iskolába és a helyi közösségi életbe se kapcsolódnak be. Ezek a változások kihatnak a lakosság mindennapjaira, családi és közösségi életére. A vidéki térségek átalakulásának helyzete a magyar lakosság több mint felét érinti. 
Fontos tisztázni, hogy a tanulmány a vidéki térségek alatt ${ }^{1}$ nem csak a falvakat, aprófalvakat érti, hanem azon településeket is, melyek ugyan városi címet viselnek, de nem töltik be a városi szerepükből fakadó társadalmi és gazdasági funkcióikat. A települések besorolását a 2015-ös KSH Magyarországi Településhálózata 2. Városok-falvak címü írásnak megfelelően végezzük el. A településhálózat egyik nagy csoportját, a városokat nem a népességnagyság alapján osztályozták, hanem funkció szerint. Tíz fô tényezőt vettek számításba: népesség, szolgáltatások, vendéglátás, egészségügy, szociális ellátás, oktatás, kultúra, ügyintézés, munkaerő megtartás és-vonzás, gazdasági potenciál. E tényezőkhöz a jellemzésükre alkalmas mutatókat rendeltek, melyek a számítások alapját képezték és ennek megfelelően váltak csoportosíthatóvá a települések.

Hat településcsoportot alakítottak ki: fóváros (településszám: $1 \mathrm{db}$ ), felsőfokú központ (településszám: $8 \mathrm{db}$ ), középfokú központ (településszám: $29 \mathrm{db}$ ), alsófokú központ (településszám: $308 \mathrm{db}$ ), falu (településszám: $1.684 \mathrm{db}$ ) és aprófalu² (településszám: $1.124 \mathrm{db}$ ).

A 3154 településből 346 város és 2.808 község, melyből 118 nagyközség ${ }^{3}$. Jól látható, hogy a magyar települések többsége vidéki térséghez tartozik és a magyar lakosságból 2014-ben 5.700.000 fó vidéken élt (1. táblázat).

\begin{tabular}{|l|l|l|}
\hline Településhierarchia & Lakosságszám kerekítve (fö) & Településszám (db) \\
\hline Főváros & 1.700 .000 & 1 \\
\hline Felsőfokú központ & 1.100 .000 & 8 \\
\hline Középfokú központ & 1.300 .000 & 29 \\
\hline Alsófokú központ & 2.800 .000 & 308 \\
\hline Falu & 2.600 .000 & 1.684 \\
\hline Aprófalu & 300.000 & 1.124 \\
\hline Összesen & $\mathbf{9 . 8 0 0 . 0 0 0}$ & $\mathbf{3 . 1 5 4}$ \\
\hline
\end{tabular}

Forrás KSH (2015) alapján saját szerkesztés.

1. táblázat: Településhierarchia lakosság- és településszám szerint.

Enyedi György (1980) már említett írásában foglalja össze negyedszázados kutató munkáját a falvakkal kapcsolatban, mely a falvak és a városok között funkcionális különbségek meghatározására irányult. „A funkcionális értelmü városi települések száma Magyarországon mintegy 130-150, míg városi jogállással csak 96 település rendelkezik" (Enyedi, 1980:11). Napjainkban ez a helyzet jelentősen átala-

\footnotetext{
${ }^{1}$ A tanulmány a tanyák helyzetére nem tér ki.

${ }^{2}$ A 2005. évi Országos Területfejlesztési Koncepció szerint az 500 főnél alacsonyabb lélekszámú településeket tekintjük aprófalunak.

${ }^{3}$ 2011. évi CLXXXIX törvény alapján 3000 fő is elegendő a nagyközség címhez.
} 
kult, míg korábban a városok száma kevesebb volt, mint a városi funkciókat betöltő településeké, ez a kilencvenes évektől megváltozott, 2013-ban 346 település rendelkezett városi címmel 1990 és 2011 között a városok számának rohamos növekedése nem járt együtt a városi funkciót betöltő települések számának lényeges emelkedésével. Gondoljunk csak olyan településre, mint Pálháza (1.062 fö), Igal (1.336 fó), Zalakaros (1.764 fö), Pacsa (1.904 fö), Gönc (2.060 fö), Máriapócs (2.130) Vaja (3.515 fö) és még lehetne sorolni sok más hasonló nagyságú települést, mely városi ranggal büszkélkedhet. Jól látható, hogy a városok mennyiségének növekedése, az urbanizáció, nem jár együtt a fejlődéssel, jobb életszínvonallal és azt is el kell ismernünk, hogy Magyarország a városok nagy száma ellenére vidéki térségekben bővelkedik.

\section{Funkcióját vesztett falvaink}

A rendszerváltás fő vesztesei a vidéki térségek és települések voltak. A termelőszövetkezetek szétesésével megszüntek a munkahelyek a mezőgazdaságban, az iparban való elhelyezkedési esélyek is csökkentek, azzal, hogy sok iparág megszünt, illetve az átalakult gazdaság foglalkoztatói más típusú tudásra tartottak igényt.

1980-ban ,egy átlagos magyar faluban 1.800 ember él; 57\%-uknak van kereső foglalkozása (a foglalkoztatottak 40\%-a a mezőgazdaságban, 37\%-a az iparban dolgozik); átlagos életkoruk 37,4 év" (Enyedi, 1980:16). Több évtized elteltével a vidéki foglalkoztatottság nagyban átalakult. A foglalkoztatottság a KSH 2013as évi adatai szerint (2. táblázat) az alsófokú központokban, azaz a kisvárosokban $46,1 \%$, a falvakban 43,1\% és az aprófalvakban 39,2\%. A falvakban élő foglalkoztatottaknak több mint $60 \%$-a ingázik naponta, míg a vidéki városok munkavállalói kedvezőbb helyzetben vannak, mivel csak(!) 40\%-uk ingázik (2. táblázat). A vidéki lakosság legnagyobb foglalkoztatója az önkormányzat (Perger, 2015). Természetesen ezt a helyzetet nagyban befolyásolhatja a település elhelyezkedése, mely a helyi lakosság foglalkoztatottságára erősen kihat. Egy nagyváros közelségének hatására, különösen, ha a település szuburbanizálódó környezetben található, az ipar, a szolgáltató, és az infokommunikációs szektor lehetőségei kigyürüznek a vidéki településeken élök foglalkoztatottságára. 


\begin{tabular}{|c|c|c|c|}
\hline Főbb mutatószámok, 2013 & $\begin{array}{l}\text { Alsófokú } \\
\text { központok }\end{array}$ & Falvak & $\begin{array}{l}\text { Aprófal- } \\
\text { vak }\end{array}$ \\
\hline Települések száma, db & 308 & 1.684 & 1.124 \\
\hline Népesség száma, fó & 2.792 .018 & 2.632 .515 & 290.735 \\
\hline Átlagos településnagyság, fö & 9.065 & 1.563 & 259 \\
\hline Száz gyermekkorúra jutó időskorú, fó & 114 & 109 & 133 \\
\hline $\begin{array}{l}1.000 \text { lakosra jutó természetes szaporodás/fo- } \\
\text { gyás, ezrelék }{ }^{\text {a) }}\end{array}$ & $-3,3$ & $-4,4$ & $-7,7$ \\
\hline $\begin{array}{l}1.000 \text { lakosra jutó belföldi vándorlási külön- } \\
\text { bözet, ezrelék }{ }^{\mathrm{a})}\end{array}$ & 0,3 & 0,0 & $-5,5$ \\
\hline Száz háztartásra jutó személy, fởb) & 247 & 258 & 248 \\
\hline $\begin{array}{l}\text { Legalább érettségivel rendelkezők aránya a } \\
18 \text { éves és idősebb népességből, \% \%) }\end{array}$ & 44,2 & 33,6 & 25,1 \\
\hline $\begin{array}{l}\text { Foglalkoztatási arány (a } 15 \text { éves és idősebb } \\
\text { népességből), \% b) }\end{array}$ & 46,1 & 43,1 & 39,2 \\
\hline $\begin{array}{l}1.000 \text { lakosra jutó müködő vállalkozások } \\
\text { száma, } \mathrm{db}^{\mathrm{c})}\end{array}$ & 56 & 41 & 37 \\
\hline $\begin{array}{l}\text { Naponta ingázók aránya a foglalkoztatottak- } \\
\text { ból, \% } \% \text { b) }\end{array}$ & 40,0 & 61,3 & 66,9 \\
\hline $\begin{array}{l}\text { Egy adófizetőre jutó személyijövedelemadó- } \\
\text { alapot képező jövedelem, } 1000 \mathrm{Ft}\end{array}$ & 1.799 & 1.609 & 1.378 \\
\hline 10.000 lakosra jutó épített lakás, db & 27 & 21 & 15 \\
\hline
\end{tabular}

a)2001-2013. évek átlaga. b) 2011.évi adat. ${ }^{\text {c) }}$ 2012. évi adat.

Forrás: KSH (2015) alapján saját szerkesztés.

2. táblázat: Vidéki térségek jellemzői.

Azok a vidéki települések küszködnek leginkább a munkanélküliséggel, melyek a felsőfokú és középfokú központoktól távol helyezkednek el és e központok elérése több mint 45 percet vesz igénybe tömegközlekedéssel vagy személygépkocsival. Így az ingázási lehetőségek is csökkenek. Ha az ország településeinek elhelyezkedését nézzük, akkor láthatóvá válnak a hátrányos térségeink, melyek a megyehatár vagy az északi, a keleti és a déli országhatár közvetlen környezetében helyezkednek el és az ott élők számára nehezen közelíthetők meg napi rendszerséggel a felsőfokú vagy a középfokú központok. Faragó (2010) szerint azok a falvak lesznek képesek fejlődni, amelyek karakteres funkcióval rendelkeznek és fejlődő diverzifikáló városhoz tartoznak, melynek jó az elérhetősége.

Magyarország egyes térségei nem rendelkezik felsőfokú központtal (1. ábra), mint például Nógrád, Heves, Békés, Somogy, Tolna, Vas, Zala és Komárom-Esztergom megye. A felsőfokú központok hiánya kihat az adott térség gazdasági lehetőségeire, melyet különböző mutatókkal is meg lehet ragadni. Ezekben a térsé- 
gekben alacsonyabb a legalább érettségivel rendelkezők aránya, a foglalkoztatottsági ráta és a müködő vállalkozók száma. Hasonló lehet annak a helyzetnek a hatása is, mikor egy megyében csak egy meghatározó felsőfokú központ található, és nincs, vagy nincsenek középfokú központi városok, mint például SzabolcsSzatmár-Bereg, Hajdú-Bihar, Baranya megyének.

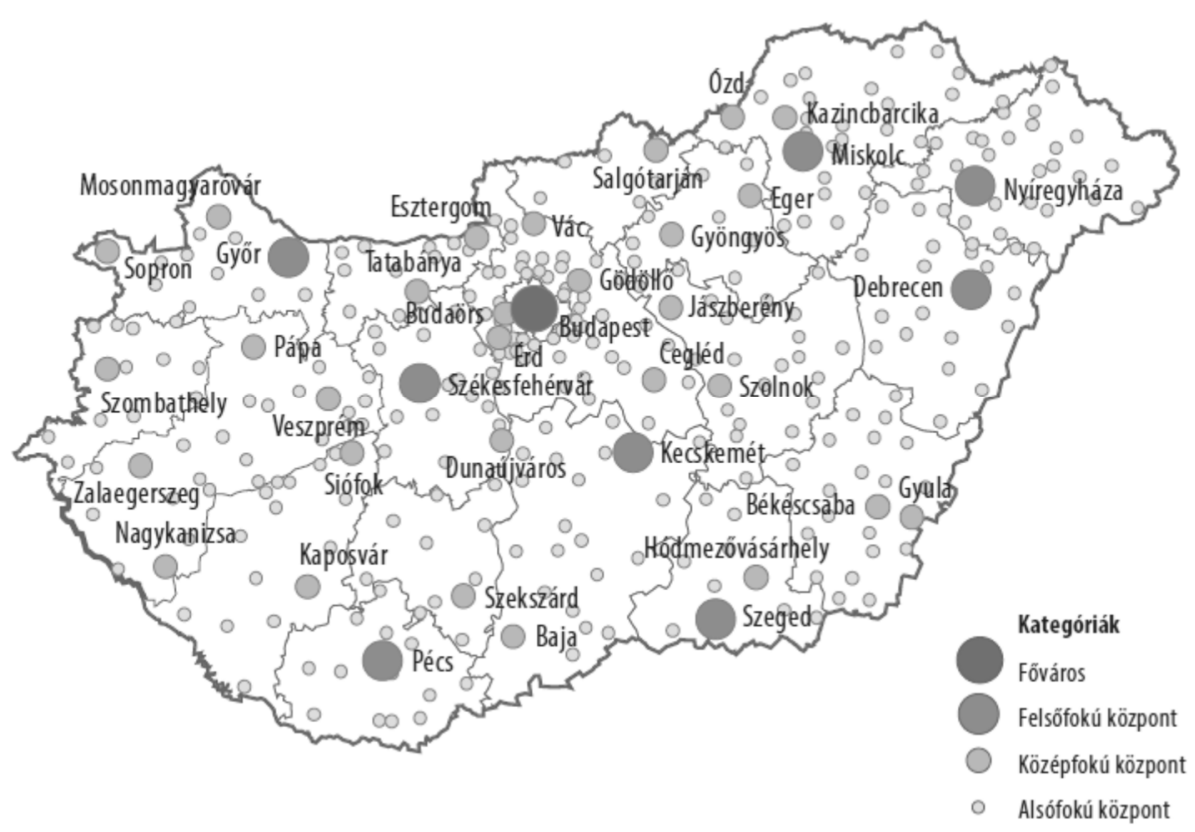

Forrás: KSH, 2015:19.

1. ábra: Kategorizált városaink.

Az alsófokú központok az 1990-es évektől nagy számba növekedtek, a KSH (2015) alapján napjainkban 308 ilyen település található (2. táblázat). Azok a kisvárosok, melyek betöltik a városi funkciókat és emellett „képességmegtartó népességgel" rendelkeznek, a környező falvakra is gazdasági hatást fejtenek ki. Városi szerepüket azzal, töltik be, hogy a helyi lakosság, valamint a közeli falvak számára magas szintü gazdasági, közigazgatási, oktatási, egészségügyi és szociális szolgáltatást nyújtanak. Ha ezek alapján vizsgálat alá vetjük az elmúlt néhány évtizedben városi címet szerzett városok szolgáltatási palettáját, kevés kisváros látja el teljes körüen a funkcióját, valamint a területszervezésü szerepét. 
Az aprófalvaink kiürülnek, míg 1970-ben a lakosság 20,7\%-a (Enyedi, 1980) élt aprófalvakban, addig napjainkban a magyar lakosságnak csak 3\%-a, 2000. és 2013. január 1-je közt 14\%-kal csökkent a népességük, ezzel szemben a többi öt településkategóriában 1-5\% volt a népességfogyás (KSH, 2015). Ezek a települések a hanyatló falusi térségek csoportját képezik. A népességfogyás hátterében az állhat, hogy nehezen érhetők el számukra a munkahelyek, közszolgáltatási egységek, valamint a szakellátás, nincs megfelelő időben, és időközönként tömegközlekedés. Enyedi (1980) lassan négy évtizede ugyanazzal a problémával szembesült, ami ma is érvényes. Nem fogadta el, hogy ,a kis lélekszámú települések fejlesztése és közlekedésének javítása nem gazdaságos. Először is nehéz a gazdaságos fogalmat társadalmi juttatásokra alkalmazni” (Enyedi, 1980:162). Napjainkban ezeknek a falvaknak több kell, mint társadalmi juttatások, gazdasági forrásokra van szükségük. Az 1970-es években a falusi lakosság jövedelmében kisebb arányba jelentek meg a társadalmi juttatások, mint a városi lakosság esetében, ez már napjainkban egyenlítődött.

A leszakadása e falvaknál fennmaradt, mivel súlyosbítja helyzetüket az, hogy Magyarországon e települések egy-egy térséget alkotnak, ilyen például: a szatmári, az ormánsági, csereháti térség, stb. ahol a társadalmi és gazdasági problémák együtt jelennek meg, gyakran pl. az elöregedéssel vagy a ,gettósodással” küzdenek. A szerző ezen meglátását támasztja alá a Magyar Tudományos Akadémia és a Magyar Nemzeti Vidéki Hálózat (továbbiakban MTA és MNVH) együttmüködése keretében 2012 és 2014 között megvalósult komplex vidékkutatási program egyik alkutatása, mely a társadalmi-térbeli marginalizációt vizsgálta a vidéki térségekben. „A társadalmi marginalizálódás és a térbeli hátrányok halmozódása nem választható el egymástól; a vidéki terek marginalizálódása az ott élő-müködő egyének, csoportok marginalizálódását is eredményezi, tovább rontva a térség helyzetét" (Nagy, Timár és munkatársai, 2015:37). A leszakadó térségeinkből hiányzik, vagy kis számban van jelen egy olyan társadalmi réteg, mely tud és akar tenni a település és a közösség fennmaradásáért. Az MTA és MNVH projekt egyik eredménye az volt Perger (2015) szerint, hogy feltárták, hogy a vidéki térségek szinte mindegyikében a legnagyobb problémát a humán szféra kapacitásának kimerülése és a „helyben maradó” pénzügyi tőke hiánya okozza.

Milyen funkcióveszteségek figyelhetőek meg vidéken? Az első mindenképen a mezőgazdasági termelés és a mezőgazdaságban való foglalkoztatottság visszaesése, az, hogy a helyben előállított termékek még saját fogyasztásra sem jelennek meg. Sok falu esetében a termőföldek tulajdonosai nem helyben laknak, munkaerő iránti igényüket sem helyiekkel oldják meg. A falusi lakosság kohézióját gyengíti az is, hogy a földek tulajdonjoga kevés számú egyénnél összpontosul.

„A koncentráció mértékét a 2010-es adatoknak az 1935-ös földbirtok adatokkal történő összehasonlítása is megmutatja. A két világháború közötti korszak földbirtokstruktúráját a kortársak és a mai történettudomány is torznak tartották 
és külön hangsúlyozták a nagybirtokok arányának a dominanciájából eredő szerkezetproblémákat. 1935-ben a hatszáz hektáron felüli birtokok tették ki az összes birtok 0,1 százalékát, amelyek a föld 29,9 százalékát használták. Az összes birtok 43,2 százalékát jelentő 100 hektáron felüli gazdaságok, a föld 43,1 százalékát használták. 2010-ben a 100 hektáron felüli gazdaságok az összes föld 72 százalékát müvelték. Az 5 hektár alatti gazdaságok 1935-ben az összes gazdaság 72,5 százalékát jelentették, amelyek a föld 10,1 százalékán termeltek. 2010-ben ugyanehhez a földnagyság kategóriához tartozó gazdaságok aránya 79,8 százalék az összes gazdaságon belül. Az 5 hektár alatti gazdaságok 2010-ben a föld 5,2 százalékát használták szemben az 1935-ös 10,1 százalékkal. A legnagyobb és legkisebb birtokkategóriák adatainak az összevetése is elég bizonyítékot adott annak az alátámasztására, hogy 2010-ben sokkal erőteljesebb a földhasználat koncentráció, mint 1935-ben volt” (Kovách, 2014:149).

A fenti adatok jól tükrözik, hogy a helyi lakosság nem kötődik a településhez, nincs kapcsolata helyi erőforrásokkal. A munkavégzési formák eltávolodnak a falvakra, vidékre jellemző munkáktól. A családok önfenntartása, az alapvető élelmiszerek megtermelése és feldolgozása a háztájiban ${ }^{4}$ eltünőben van. 2000 és 2010 között az egyéni gazdaságok száma 40\%-kal csökkent (AMÖ, 2010). 2013-ban a mezőgazdasági tevékenységet folytató egyéni gazdaságok száma 482.005, a mezőgazdasági tevékenységet folytató gazdasági szervezet pedig 8.800 volt (GSZÖ, 2013). Míg 2010-ben a kisgazdaság száma 567.000 volt, jól megfigyelhető közel 15\%-os csökkenés 2013-ra. A 2013-as (GSZÖ) összeírás idején mintegy 1,1 millió háztartás (ház körüli és az üdülőkhöz tartozó kertekben) végzett küszöbérték alatti mezőgazdasági tevékenységet.

Enyedi (1980) könyve alapján nem rendelkezünk pontos adatokkal arról, hogy a lakosság hány százaléka folytatott mezőgazdasági tevékenységet az általa vizsgált negyed évszázadban, de kellő információnk van arról, hogy a falvak gazdasági osztályozása a falusi népesség foglalkozási szerkezetén alapult. „,...községeinknek mintegy fele minősült 1970-ben mezőgazdasági jellegünek, 1/3-a vegyes jellegü, 10-15\%-a ipari jellegü. Ezek az adatok is világosan bizonyítják, hogy a falu = mezőgazdasági település képlet milyen széles körben vált érvénytelenné" (Enyedi, 1980:68). Az 1970-es évek átmeneti állapotként jelentek meg, még ugyan erősen jelen voltak a háztáji gazdaságok, a tsz melléküzemá gai és a téeszek. Az 1990-es évektől rohamosan felerősödött a mezőgazdasági foglalkoztatottak számának csökkenése.

\footnotetext{
${ }^{4}$ Itt a háztáji kifejezést nem az államszocializmus alatti értelmében használj a szerző (ami a téesz mellett a tagok által müvelt föld volt). Hanem a ház körüli kertben és a települések körüli kertségekben termelt javakat jelenti.
} 
A térségek közötti különbségek és a fejlödési diverzifikáció megfigyelhetö, de a járásokon belüli különbségek néha még markánsabbak, mint a járások közötti. A járások között alig találunk olyanokat, amelyek gazdasági értelemben az agráriumtól függenének, ugyanakkor környezeti, földhasználati szempontból erős a mezőgazdaság dominanciája a gazdasági ágazatok között (Kovács, Farkas, Perger, 2015). Azokban a vidéki térségekben, ahol az ,agrárfüggőség” erős, ott a fejlődés és a megmaradás tekintetében fontos a földhasználati koncentráció, mely kihathat a lakosság megtartására is. A felső- és középfokú városok vonzáskörzetében található falvaink lakossága számára a foglalkoztatási lehetőséget a városban kínált könnyebb munkakörülmények és a foglalkoztatási paletta bővülése jelenti, egyúttal a városi központ, valamint a vonzó városias magatartás- és életformák, a városi (agglomerációs) központok erősen hatnak a vidéki népesség mobilitására, városiasodott vidéket hozva létre egyes településekből (az agglomerációban), koptatva a hagyományos falusi funkciókat.

\section{A vidéki életmód átalakulása}

A vidék átalakulásával a falusi életmód is nagyot változott az elmúlt három-négy évtized alatt. A falusi életmódváltozás alatt Enyedi (1980) három tényezőt ért: az első a falusi gondolkodásmód, értékrend, a második az életszínvonal, jövedelem, társadalmi juttatások és a fogyasztás. A harmadik tényező az életkörülmények, mely alatt a lakóház, a falusi település infrastruktúra-színvonalát, kereskedelemi, oktatási és egészségügyi ellátást értette. A falusi gondolkodásmód és az értékrend statisztikai adatokkal nehezen kifejezhető, sokkal jobban mutatja e változást a vidéki társadalmak és közösségek önszerveződése és az életmód modernizációja. A változás, átalakulás szembetűnő még akkor is, ha csak a Kádár korszakkal (19601980) vettjük össze.

Az életszínvonal könnyebben mérhetö. A 2. ábra alapján látható, hogy az országos személyi jövedelemadó-alapot képezö jövedelem $22 \%$-át a falvak és $2 \%$ át az aprófalvak lakossága állítja elö. 


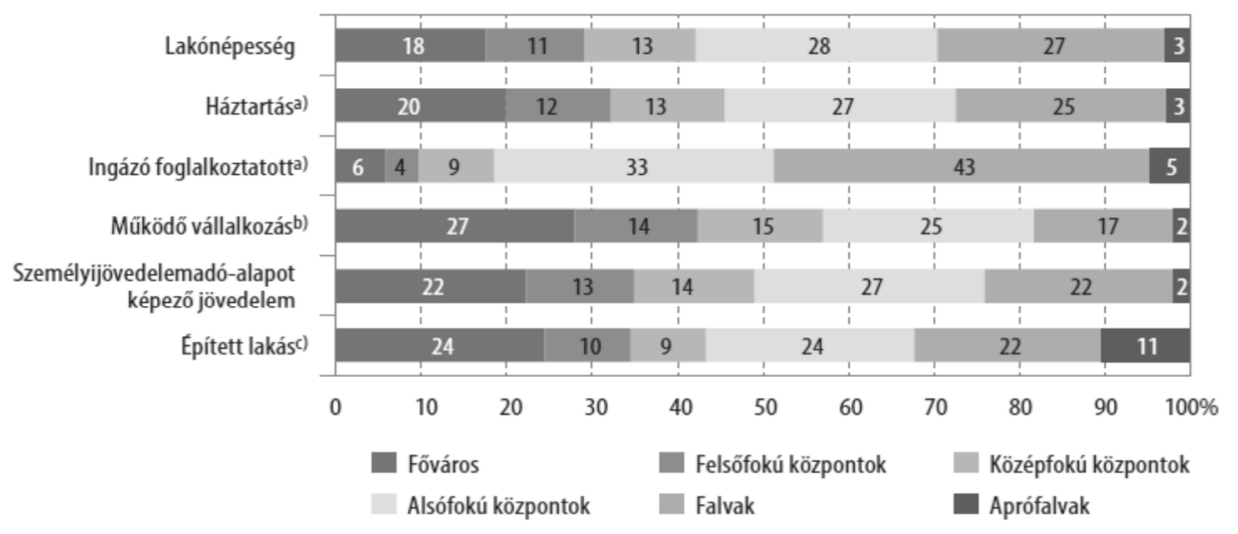

a) 2011.

c) 2001-2013.

Forrás: KSH, 2015:20.

1. ábra: A fóbb mutatók megoszlása településhierarchia-szintek szerint, 2013.

Az aprófalvakban az egy adófizetőre jutó személyi jövedelemadó-alapot képező jövedelem 1.378.000 Ft/év, a falvakban 1.609.000 Ft/év, míg a fővárosban az aprófalvak duplája, 2.628.000 Ft/év volt 2013-ban. Összehasonlítva Enyedi (1980) kutatási eredményeivel jól érzékelhető, hogy a második világháború után is nagy volt a jövedelmi különbség a falusi és a városi népesség életszínvonala között, mely csak a 1960-as évek második felétől kezdődően csökkent, a falusi jövedelmek gyorsan közeledtek a városi jövedelmekhez. „A mezőgazdasági nagyüzem átszervezésével lényegében a kisgazdák megszüntek... A nagyüzemek által biztosított háztáji (szövetkezetek), illetve illetmény (állami gazdaságok)-föld azonban lehetőséget nyújtott a kisüzemi termelésre. Ennek hivatalosan deklarált célja a rossz vidéki élelmiszerellátás miatt a családi szükségletek biztosítása, és emellett a kezdeti alacsony szövetkezeti jövedelmek miatt a kiegészítő jövedelemszerzés feltételeinek megtermelése volt (Buday-Sántha, 2001:91). Az 1960-as évek elején az állam, bár nem támogatta, de nem is korlátozta a kisgazdaságban folyó termelést, melyet már az 1960-as évek második felében felváltott a kisüzemi termelés támogatása. Ebből alakult ki az úgynevezett háztáji integrációs rendszer (BudaySántha, 2001). Az 1970-es években a kemizálás és a gépesített növénytermesztés általánossá válásával a munkaerő egy részének folyamatos foglalkoztatására már nem volt lehetőség.

Ezért inkább a termelés kihelyezésével, a háztájiban végzett munkával oldották meg a foglalkoztatást. Az 1980-as évtizedben a központi elvonások, bérkorlátozások elől a kistermelés bővítésével tértek ki. „Családi kisegítő gazdálkodással a 
falun élő családok 80\%-a foglalkozik, tehát a nem mezőgazdasági foglalkozásúak is" (Enyedi, 1980:52).

Kettős jövedelemszerzés volt a jellemző a magyar vidékre, mely napjainkban alig van jelen, melynek lényege, hogy szabadidejében a vidéki lakosság kiegészítő agrártevékenységgel foglalkozott. Statisztikai adatok alapján napjainkban 1,1millió háztartás ${ }^{5}$ végez mezőgazdasági termelést a családja számára. Ez a háztáji, másodikgazdaság többnyire generációkról generációkra átadott tudás és öngondoskodás, mely napjainkban nagyban különböznek az 1970-1980-as évek gazdálkodásától. Többnyire gyümölcstermesztés, kertészeti növénytermesztés, esetleg állattenyésztés formában van jelen. Azokban a falvakban jelenik ez meg nagyobb mértékben, ahol a háztáji gazdaság az 1970-es évektől nagy szerepet töltött be a családok jövedelemszerzésében és prosperálóan tudták e munkát végezni napjainkkal ellentétbe. „Ezért a falvakban található a társadalmunk legmagasabb jövedelmü rétege is, nemcsak a legalacsonyabb jövedelmü" (Enyedi, 1980:53).

A növénytermesztéshez hasonlóan az állattenyésztést is bérbe adták, és vállalkozókkal működtették az 1970-es évek második felétől. Ez a megoldás a részidős foglalkoztatásból a fóállású vállalkozási konstrukcióba vezetett át (BudaySántha, 2001).

A mezőgazdasági termelőszövetkezetek anyagi-pénzügyi helyzetének megerösödése a vidéki lakosság számára lehetővé tette a jelentős „,civilizatorikus” fejlődést. Az 1980-as évtizedben megjelentek a nagyobb területü és magasabb komfortfokozatú lakások. A vidéki lakosság körében is érezhetővé vált az életszínvonal növekedése, amit a vizsgált falvak ingatlanállománya kellőképpen tükröz. A falvak lakásállománya (KSH 2015) 22\%-a, az aprófalvak állománya 11\%-a a magyarországi épített lakásoknak, miközben a falvakban a lakosság 27\%-a és aprófalvakban 3\%-a él. Az aprófalvaink esetében a százalékos arányszám -különbségek jól érzékeltetik a kiüresedett lakásingatlanok nagy számát. A többi településtípus adataival összehasonlítva megállapítható az is, hogy a legnagyobb eltérés a lakosság és a lakásállomány százalékos értéke között az aprófalvaknál figyelhető meg.

Ha tovább vizsgáljuk az elmúlt évtizedeket, akkor ismét ok-okozati kapcsolatot vélünk felfedezni a múlt és a jelen között, az 1980-as évek végén újabb fordulat következett, mely kihat a vidék mai életére. A keleti agrárexport visszaesése és az ehhez kapcsolódó támogatások csökkenése a mezőgazdaságban hatalmas bevételkiesést okozott, aminek következtében a mezőgazdasági szektorban dolgozók jövedelme is nagyot zuhant. 1989 után radikálisan megváltozott Magyarország gazdasági helyzete. Az általános és nemzetgazdasági válság fö terheit a falusi-vidéki térségeknek kellett elviselniük. Az ipari, építőipari munkahelyek megszünésének döntő hányada is a falusi lakosságot érintette. Egyrészt először a „több pénzbe

\footnotetext{
${ }^{5} \mathrm{Az}$ adat soknak tünik akkor, ha falvainkat járjuk és a tapasztalatainkat vizsgáljuk. Jelentek meg olyan adatok is, hogy a magyar lakosság 46\%-a azaz 3,6 millió termel valamit.
} 
kerülő" ingázókat bocsátották el, így megszabadultak az utazási költségtérítéstől. Másodrészt a nagyvárosi vállalatok megrendelésének csökkenése következtében először a vidéki, falusi telephelyeiket zárták be, számolták fel. Harmadrészt ugyancsak a megrendelések csökkenése, a mezőgazdasági nagyüzemek ipari, építőipari és egyéb kiegészítő tevékenységeit is érintette (Illés, 1995). Valamint az a tény is megfigyelhető volt, hogy a „,kétlaki” (ingázó) vidéki munkavállalók képzettsége, iskolázottsága sok esetben alacsonyabb volt, mint a városiaké.

Az 1980-1982-ben újból piaci reformokkal kísérletezett a magyar gazdaság és a politikai vezetés. 1982-ben megjelentek a gazdasági munkaközösségek (GMK), valamint a kisszövetkezetek. „Az újabb reform fontos mellékszála volt a félmagán és magánvállalkozások hátrányos megkülönböztetésének megszüntetése, új formáinak, a kidolgozása is.... A magán kisiparban is lazult a szabályozás" (Laki, 1998:11). Az összes kisiparos száma 1975-ben 84.000, 1985-ben már 145.000 fö volt (Statisztikai Évkönyv, 1985). „A növekedés az évtized második felében is folytatódott, 1989-ben már 174.000 kisiparos tevékenykedett az országban (Magyar Statisztikai Zsebkönyv, 1990:192). A vállalkozásalapítások általában 1989 után kezdődtek többnyire a második gazdaságból kiindulva, agrár-, illetve kiskereskedelmi, kisipari területeken. Továbbá a korábbi „,fusizók”, valamint a vállalkozásra nyitott, erős szakmai képességekkel rendelkező egyének elhagyták a munkahelyüket, annak reményében, hogy jobb kereseti lehetőséget, valamint nagyobb függetlenséget élvezhessenek tervezett vállalkozásukban. Vállalkozásuk típusa igazodott a végzettségükhöz, illetve az addigi tevékenységükhöz, tapasztalatukhoz. Azon vállalkozók, akik ez időben „céget” alapítottak, kis kockázatot vállaltak, kis pénzbeli befektetéssel (Ludescher, 2010).

„A munkahely elvesztésének növekvő esélyeivel nőtt a vállalkozás kockázata is, hiszen a korábbinál nagyobb erőfeszítést igényelt az állami állások egyidejü megtartása, illetve az állami munkahelyekre visszalépés.... Elsősorban ez a teljesítmény és légkör befolyásolhatta ebben az időben a vállalkozni szándékozók várakozásait. Sokan gondolhatták azt, hogy miközben a kisvállalkozás politikai kockázatai csökkentek, az árupiaci, munkaerő-piaci kockázatok vállalhatók" (Laki, 1998:47-48). Az 1990-es évek közepe felé kényszer hatására megjelent egy új vállalkozótípus. Ezek a vállalkozók elveszítették munkájukat, illetve a munkahelyükre való ingázás feltételei ellehetetlenítették a munkavállalásukat. A létfenntartás érdekében e társadalmi csoport önfoglalkoztatóvá válik. A vállalkozásbeli befektetés esetükben minimális, a cég müködtetését a legtöbben átmenetinek gondolták. De arra is van példa, hogy később e vállalkozások müködésükben túlnövik a kezdetben vele szemben támasztott igényeket (Laki, 1998; Ludescher, 2010).

Emellett megjelentek az 1990-es évek második felében az önmegvalósító vállalkozók, akiket a külföldi szakirodalom „self made man”-nek nevez. E csoportot olyan egyének alkotják, akiknek erős a belső motiváltságuk, és vállalkozásukat a 
társadalmi lehetőségeket kiaknázva hozták létre. Előzetes (Ludescher, 2010) vizsgálatok azt mutatják, hogy az önmegvalósító vállalkozók kis számban jelentek meg a vidéki térségekben, ezen belül is a hátrányos térségekben. Ha a müködő vállalkozók százalékos arányát tekintjük, akkor a vidéki térségekben kimagaslóan nagyobb számba működtek vállalkozások. Magyarországon a KSH (2015) adatok alapján a müködő vállalkozások $27 \%$-a a fövárosban, $14 \%$-a a felsőfokú és $15 \%$ a a középfokú központokban müködnek, míg 44\%-a a vidéki térségekben (25\%ban alsófokú, $17 \%$-ban falvakban és $2 \%$-ban aprófalvas településeken). Sok esetben a vállalkozás létrehozásában az játszik szerepet, hogy egyes térségekben az önfoglalkoztatás az egyetlen kiút (Kovács, Váradi, 2013). További kérdést vet fel a vállalkozások mérete, hogy köztük mennyi pl. a mikro- vállalkozások aránya.

Láthattuk az eddigiekben, hogy a vidéki életmód, a munkalehetőségek, ezzel együtt a jövedelem hogyan változott, de még nem szóltunk arról, hogy az életkörülmények milyen változásokon mentek keresztül. A KSH (2015) adatok alapján az aprófalvak lakásállománya 82,9\%-a 1980 elött épült és csupán 33,1\%-a összkomfortos, 19,3\%-a komfort nélküli. A falvakban az aprófalvakhoz hasonló a helyzet, annyiban tér el, hogy jóval kevesebb ház van használatban az 1945 előtti évekből (a lakások 38,4\%-a 1945 előtt épült az aprófalvakban, a falvakban pedig 21,2\%-a).

Az alsófokú településeken a lakások felét 1946-1980 között építették, 56,8\%uk összkomfortos, míg a falvak lakásállományának csak 45,9\%-a felel meg az összkomfort fokozatnak 2013-ban (KSH, 2015). Összegzésként a vidék a lakhatási körülményeit tekintve továbbra is elmarad a fővárosi, felsőfokú és középfokú központokétól, az elmúlt három és fél évtized nem csökkentette a lemaradást, hanem még nagyobb kihívással állította szembe a vidéki lakosságot. Az 1946-1980 között épült lakásállományt korszerüsíteni szükséges, hogy megfeleljen a mai hőtechnológiai eljárásoknak. Említést érdemel az is, hogy a második gazdaságból való pénzkimentés céljából olyan nagy kétszintes házak épültek, hogy sok esetben a mai napig nem építették és lakták be a felső/tetőtéri szintet, nem hogy felújításra képesek lettek volna a tulajdonosaik.

A vidéki életkörülmények vizsgálatánál nagyon fontos bemutatni azt, hogy a vidéki lakosság hogyan jut egészségügyi alapellátáshoz, ezen belül is háziorvosi és fogorvosi ellátáshoz. Az Állami Egészségügyi Központ (www/1.) adatbázisát vizsgálva egyes vidéki térségekben 2004. október 1-je óta nincs betöltve háziorvosi vegyes vagy felnőtt praxis. A listából szemezgetve kiemelhetők azok a települések, melyekben több mint 13 éve nincs alapellátás. Ilyen település: Ibafa, Nemeske (Baranya); Izsák, Imrehegy (Bács-Kiskun); Körösnagyharsány, Magyardombegyháza (Békés); Ároktő, Csobaj, Felsőgagy, Hernádvécse, Putnok (Borsod-Abaúj-Zemplén), Nagylak (Csongrád); Mezősas, Újiráz (Hajdú-Bihar); Átány (Heves); Tiszabő, Mezőhék (Jász-Nagykun-Szolnok); Lenti (Zala). 2017. 
november 1-ei adatok alapján 352 háziorvosi (gyerek, felnőtt, vegyes) és 284 fogorvosi körzet nincs betöltve Magyarországon ${ }^{6}$. A betöltetlen körzetek többnyire hátrányos, nehezen megközelíthető településeken vannak. Ha megyék szintjén vizsgáljuk, akkor kimagasló a betöltetlen körzetek ${ }^{7}$ száma: Borsod-Abaúj-Zemplénben 44, Békésben 27, Bács-Kiskunban és Jász-Nagykun-Szolnokban 23, Szabolcs-Szatmár-Beregben 16 stb. A számok mögött sok tényező bújik meg, a fiatal orvosok nem akarnak olyan körzetben dolgozni, ahol sok a halmozottan hátrányos beteg, nem látnak szakmailag fejlődési lehetőséget, nem vonzó számukra, hogy helyben kevés az értelmiségi, szellemi társ. Három-négy évtizeddel ezelőtt minden körzet rendelkezett orvossal, mivel az orvosokat központilag helyezték ki, de ennek ellenére ,...a falusi térségen belül még az alapellátásban is igen nagy különbségeket találunk" (Enyedi, 1980:61). A különbségek továbbra is fennmaradtak, a kisebb falvainkban élők jelentős hátrányokat szenvednek el, többek között a sok közlekedésre fordított idő miatt. A vidéki városaink szakellátásai, kórházai is küszködnek helyi szakorvos hiánnyal és emellett központilag integrálni próbálják a járási járó beteg ellátást egy-egy megyei vagy kiemelt szakellátó központhoz a gazdaságosság nevében.

A hátrányos helyzetü települések további problémája, hogy a cigány kisebbség aránya a lakosságon belül növekszik. „A megbillent demográfiai és társadalmi szerkezet nem csak a helyi erőforrások elvesztésével (pl. oktatási intézmények bezárása) járhat. A szelektív elvándorlás a gettósodás kiteljesedéséhez, mélyszegénységben élő roma népesség településen belüli arányának növekedéséhez vezet, de ott is a szegénység mélyülését eredményezi, ahol nem vagy minimális számban élnek romák" (Váradi, 2015:75). Ha a romák és a nem romák között nyílt konfliktusok nem is tapasztalhatók, a szerző előzetes kutatásai során azzal találkozott (Ludescher, 2010), hogy a nem cigány lakosság viszonyulása változik meg a településsel kapcsolatban. Igy például a szülök nem kívánják olyan óvodába, iskolába járatni gyermekeiket, melyben leendő osztálytársaik cigány származásúak. A szolgáltatások minőségi különbségei (például az oktatásban) egyértelmüen a térbeli egyenlőtlenségek újratermelődését, sok esetben a szegregációt erősítették a vidéki terekben is" (Nagy, Timár és munkatársai, 2015). Kialakulnak szegregált iskolák olyan településeken is, ahol a roma etnikai lakosság kisebbségben él. A nem cigány gyerekeket elviszik távolabbi iskolákba, a fiatalok elvándorolnak, és ez a nem roma lakosság fokozatos elöregedéséhez vezet. E folyamat mellett meg-

\footnotetext{
${ }^{6}$ A magyar kormány anyagi támogatása (hat millió vissza nem térítendő támogatás) mellett a 2016-os évben 23 háziorvosi körzet lett betöltve, még továbbra is maradt 352 betöltetlen körzet.

${ }^{7}$ Egy körzetnek általában egy településnek fel meg ez alól jelen esetünkben csak egy pár eset kivétel amelyek kisvárosok.
} 
jelenik szociális migráció jelensége is. „A szociális migráció nemcsak a helyi ellátórendszert állítja kihívások elé, de igen erős feszültségeket, konfliktusokat gerjeszt a nem romák és a romák, illetve a tősgyökeresnek tekintett és az újonnan érkezett romák között" (Váradi, 2015:75). Kihívás az is, hogy ha a tősgyökeres lakosság nem vándorol el, csak egy másik faluban, városban talál a gyermekének iskolát. Így az új generáció nehezebben szerez a településen barátokat, idegen marad számára a helyi lakosság és környezet. Az érzelmi eltávolodás a későbbiek folyamán tovább fokozódik, a faluját csupán lakhelynek és nem otthonának tekinti. A lokalitáson alapuló identitástudat a fiatal számára megszünik.

\section{Vidéki habitus és gondolkodás}

Hogy a vidéki gondolkodásmód alatt mi érthető, nehéz meghatározni, de érezzük, hogy a vidék és a városi lakosság ebben is különbözik egymástól, valamint azt is megfigyelhető, hogy egy komoly átalakulás megy végbe ezen a területen is. A KSH (2015) adatok elemzése Enyedi (1980) kutatásával összevetve a vidék mérhető adataiban (pl. lakosság, foglalkoztatottak, ingázok, lakás állomány számában, stb.) állandó változás és fennmaradás figyelhető meg. A vidék belső tartalmi változásának kimutatása, - mint például a vidéki habitus, gondolkodásmód - sokkal nehezebb. Enyedi (1980) se részletezi, hogy ez alatt pontosan mit ért, hivatkozik arra, hogy néprajzkutatók, antropológusok, filozófusok és szociológusok szakértelme alkalmas erre a feladatra. A rendelkezésre álló szakirodalom (Szilágyi, 2008; Kovách, 2007) a vidékkel kapcsolatos gondolkodásmódot kutatják ugyan, de más-más szemszögből. A néprajzkutatók vizsgálatai többnyire egy falura, vagy tájegység lakosságára szükül le vagy esetleg a hagyományok megőrzésére. A gondolkodás leírására alkalmazzák az együttműködés, a habitus, a munkamorál, motiváció, valamint a helyi társadalom értékrendje és szolidaritás fogalmát. E tényezőknek nagy szerepük van egy falu, közösség életében, esetleges sikerességében. E tényezők segítenek abban, hogy olyan közösségek jöjjenek létre, amelyek képesek arra, hogy egyes vidéki térségekből például csökkentsék az elvándorlást.

A falusi gondolkodáson a történelem számos nyomot hagyott és állandó változásnak volt kitéve. A vidéki életében a mindennapok során jól megragadható volt az Istenbe vetett hit, az öngondoskodás, a közösségi szolidaritás és az együttmüködés. A változás eredménye napjainkban abban megmutatkozik, hogy a vidéki templomaink kiürültek, a harangszók már nem hordoznak tartalmakat. Sok település esetében elhagyott kerteket, szőlő területeket, állat istállókat találunk a falvak bejárása során. Az öngondoskodás igénye eltünőben van, mert nincs igény rá és talán nem is gazdaságos. A Szilágyi Miklós (2008) által vezetett falukutatás eredményei feltár- 
ták, hogy a vizsgált településeken már nem a szegény családok tartanak sertést, nyulat, baromfit vagy termesztenek zöldséget és gyümölcsöt, hanem a helyi viszonyokat tekintve közepes vagy jobb anyagi helyzetben lévő családok.

Míg falvainkban az 1980-as évekig kalákában épültek a házak, addig a 21. században azt se tudják a lakosok, hogy ki a szomszédjuk és az mivel foglalkozik. A közösséget családi, rokoni viszonyok fonták össze, mára ez a kapcsolat kisebb értéket képvisel, a gyerekek tanulmányuk befejeztével nem látnak perspektívát egy hátrányos vagy csak a megyeközponttól távoli településen való letelepülésre (Kovács, 2010).

\section{Összegzés}

Összehasonlítva Enyedi György (1980) elemzését a KHS (2015) adataival és elemzéseivel megállapítható, hogy a vidéki lakosság aránya csökkent, a vidéki városok száma pedig nőtt. Továbbra is fennmaradt a szakadék a vidék és város (felsőfokú és középfokú központ) között. A vidéki térségeink között is nagy különbségek mutathatóak ki. Az aprófalvas térségeink hanyatló falusi térségé változnak.

Az életmódban és gondolkodásban nagy változás ment végbe, sok esetben hasonló a vidéki életmód a városiéhoz, de az életkörülményekben továbbra is lemaradás figyelhető meg. Alacsonyabb a továbbtanulási arány, az alapellátási és a szakellátási szolgáltatásokhoz való hozzáférést akadályozza a település nagysága és a felsőfokú központtól való távolság.

A másodelemzések megerősítik, hogy a vidéki térségeink funkcióvesztésen mennek keresztül, mely nem azonos mértékü, függ a település nagyságától, térbeli elhelyezkedésétől és társadalmi összetételétől. Egyes térségeink kisebb változáson mentek keresztül az elmúlt évtizedekben, míg mások olyan társadalmi, gazdasági átalakuláson, mely a leszakadásukat eredményezi. Jóllehet, hogy ez sok esetben előre prognosztizálható volt. A megújulás még mindig lehetséges a közösségi erő és a belső erőforrások kiaknázásával.

Összességében megállapítható, hogy az adatok, helyzetképek elemzésével a tanulmány alátámasztja, hogy Enyedi (1980) a falvak jövőjével kapcsolatos legvalószínúbb elképzelése, miszerint a falvak és a városok hosszú távon fennmaradnak, miközben belső tartalmuk, kapcsolatuk változik, több évtized elteltével is a legelképzelhetőbb szcenárió.

\section{Felhasznált irodalom}


1. Buday-Sántha A. (2001): Agrárpolitika - vidékpolitika. Budapest - Pécs: Dialóg Campus Kiadó.

2. Csatári B. (2012): Falvaink sorsa 2012, Megjegyzések az elmúlt három évtized magyar vidéki változásaihoz, Területi Statisztika 6 évf. 552-564.

3. Enyedi Gy. (1980): Falvaink sorsa, Gyorsuló idő, Budapest.

4. Faragó L. (2010): Településfejlesztés: Vitaindító tézisek, Tér és Társadalom 24 évf. 3. szám. 209-211.

5. Illés I. (1995): Falupolitika-agrárpolitika. In. Kovács Teréz (szerk): III. Falukonferencia A mezőgazdaságtól a vidékfejlesztésig. Pécs, MTA Regionális Kutatások Központja, pp. 49-57.

6. Kovách I. (2007): Vidékiek és Városiak, A tudás és imázs használat hatásai a vidéki Magyarországon. L'Harmattan- MTA PTI.

7. Kovách I. (2014): A birtokrekonstrukciós módszer lehetőségei a magyar mezőgazdaság birtok- és földhasználat szerkezetének a kutatásában, Metszetek 3. szám, 148-152.

8. Kovách I. (2016): Földek és emberek Földhasználók és földhasználati módok Magyarországon MTA Társadalomtudományi Kutatóközpont, Debreceni Egyetemi Kiadó, Budapest.

9. Kovács A. D., Farkas J. Zs., Perger É. (2015): A vidék fogalma, lehatárolása és új tipológiai kísérlete. Tér és Társadalom 29(1), 11-34. DOI: 10.17649/TET.29.1.2674

10. Kovács K., Váradi M. M. [szerk.] (2013): Hátrányban vidéken. Argumentum, Budapest.

11. Kovács T. (2010): A paraszti gazdálkodás és társadalom átalakulása. L’Harmattan Kiadó, Budapest.

12. Központi Statisztikai Hivatal (2010): Általános Mezőgazdasági Összeírás, Budapest.

13. Központi Statisztikai Hivatal (2013): Gazdaságszerkezeti Összeírás, Budapest

14. Központi Statisztikai Hivatal (2015): Magyarországi Településhálózata 2. Városok-falvak, Budapest.

15. Laki M. (1998): Kisvállalkozás a szocializmus után. Közgazdasági Szemle Alapítvány, Budapest.

16. Ludescher G. (2010): A vállalkozások és a közösségek szerepe a rurális térségek megújulásában, Kiadó: Hőnyi Pál, Pécs. 
17. Magyar Tudományos Akadémia és a Magyar Nemzeti Vidéki Hálózat együttmüködése keretében 2012 és 2014 között megvalósult komplex vidékkutatási program.

18. Magyar Statisztikai Évkönyv (1990): Magyar Statisztikai Évkönyv. Központi Statisztikai Hivatal, Budapest.

19. Nagy E., Timár J. és munkatársai (2015): A társadalmi-térbeli marginalizáció folyamatai a leszakadó vidéki térségekben. Tér és Társadalom 29(1), 35-52. DOI: 10.17649/TET.29.1.2680

20. Perger É. (2015): A Magyar Tudományos Akadémia és a Magyar Nemzeti Vidéki Hálózat együttmüködése keretében megvalósult komplex vidékkutatási programról, Tér és Társadalom 29(1), 3-10.

DOI: 10.17649/TET.29.1.2698

21. Statisztikai Évkönyv (1985): Statisztikai évkönyv. Központi Statisztikai Hivatal, Budapest.

22. Szilágyi M. (2008): Sors és tapasztalat MTA Néprajzi Kutatóintézete, Budapest.

23. Varga A. Tamás - Vercseg Ilona (1991): Település, közösség, fejlesztés: tapasztalataink a helyi társadalmi-kulturális fejlesztésről, Országos Közmüvelődési Központja, Budapest.

24. Váradi M. M. (2015): Szegénység, projektek, közpolitikák. Tér és Társadalom 29(1), 69-96. DOI: 10.17649/TET.29.1.2678

(www/1): http://www.oali.hu/praxiskezelo-nyilvtartas/tartosan-betoltetlenkorzetek (látogatva: 2017. november 30.)

\section{Dr. Ludescher Gabriella}

Szociológus, $\mathrm{PhD}$ fokozatot szerzett regionális politika és közgazdasági tudományokból. A Debreceni Egyetem Egészségtudományi Kar Szociális és Társadalomtudományi Intézetének adjunktusa. 